\title{
THE SASKATCHEWAN POTASH PRORATIONING SCHEME
}

\author{
WILLIAM F. READY, Q.C.*
}

\begin{abstract}
The purpose of oil and gas conservation legislation is the prevention of waste and the protection of correlative rights. The oil and gas lawyer is fami. liar with these reasons as the basis of oil prorationing, but when one turns to the problem of potash prorationing, it can readily be seen that the correla. tive rights purpose is not applicable since potash, being a hard rather than a fugacious mineral, does not migrate across property boundaries. As such, the problem arises whether potash prorationing can be justified on the basis of prevention of waste, both physical and economical, in a situation where over production of potash leads to cutthroat competition, to an uneconomic price for potash, to highgrading and other wasteful mining practices and to the possibility of a closing of potash mines. This article discusses the Saskatchewan Potash Conservation Regulations as of June, 1970, and concludes with the observation that a producer who wished to challenge the validity thereof may "win the battle but lose the war."
\end{abstract}

\section{A. INTRODUCTION}

The Province of Saskatchewan, with its vast reserves of potash, took pride in calling itself and being called, "The Potash Capital of the World." Initially, it was felt that the production of potash would be a boon to all involved, including the Province of Saskatchewan, this proving particularly true for a few years. With the price of potash at a high of about $\$ 26.00$ a ton in 1964 , the inducement to produce as much potash as possible was great. However, as more and more mines were brought into production, the supply of potash outstripped the demand, with the result that the price for potash decreased to a low of about $\$ 10.00$ a ton in 1969 .

For some time-perhaps a couple of years, prior to 1969, the necessity for some type of prorationing of production had been recognized by those involved, but no positive agreement had been reached as to implementation of such prorationing. However, by at least mid-1969, it became necessary for something to be done, and to be done rather quickly, to limit the production of potash. What led to this necessity? Some of the factors are as follows:

1. Since the percentage of potassium oxide in potash produced at Carlsbad, New Mexico, was considerably less than the percentage in potash produced in Saskatchewan, Saskatchewan producers were able to sell their potash in the United States more cheaply than those producing potash at Carlsbad. This prompted the United States of America to consider anti-dumping penalties to deter the export into the United States of Saskatchewan potash. There is a large market in the United States for Saskatchewan potash, and it therefore became of paramount importance that everything possible be done to make it unnecessary for such penalties to be imposed.

2. Since royalty payable to the Province as to potash produced from Crown lands was based on "the net selling price of mine run ore" a low price for potash had the same effect on the royalty revenue.

3. There was concern that if production continued unchecked,

\footnotetext{
- Barrister and Solicitor, McDougall, Ready, Wakelink, Youck and Evans, Regina, Saskatchewan.
} 
with the price of potash remaining low, some companies involved might be unable or unwilling to continue operations, with the resultant adverse effect on the Saskatchewan economy. The potash companies being unable, or unwilling, to agree among themselves, to limit production, the Province of Saskatchewan took on the task, with the result that on November 17th, 1969, The Potash Conservation Regulations, $1969,{ }^{1}$ were born.

\section{B. THE POTASH CONSERVATION REGULATIONS, 1969}

The authority to make these regulations is based, as in the Regulations set forth, on the following provisions of The Mineral Resources Act, ${ }^{2}$ namely:

3. The purposes of this Act are:

(a) to promote and encourage the discovery, development, management, utilization and conservation of the natural resources of Saskatchewan;

(b) to regulate the disposition of Crown mineral lands;

(c) to protect the correlative rights of the owners of surface rights and of mineral rights.

9. The Minister may do such things as he deems necessary to discover, develop, manage, utilize and conserve the mineral resources of Saskatchewan...

10. (1) The Lieutenant Governor in Council may make such regulations and orders not inconsistent with this Act as he may deem necessary for the purpose of carrying out its provisions according to their obvious intent or to meet cases that may arise and for which no provision is made therein ...

As originally ordered, the Regulations provided for the issuance by the Minister of Mineral Resources of a producing license and a disposal license in such form and subject to such conditions as the Minister might determine. Without a producing license, no potash could be produced on and after January 1st., 1970, and without a disposal license no potash could be disposed of on and after that date. ${ }^{3}$

On March 19th., 1970, by Order in Council the provisions relating to a production license and a disposal license were rescinded, and a new provision was ordered which provided that the production of potash was prohibited unless a producing license was granted by the Minister on such basis, in such form and subject to such conditions as the Minister might deem appropriate to each proposed production, including disposal thereof. While the words "subject to such conditions as the Minister might deem appropriate" seem to clothe the Minister with the widest discretion and authority, the amendment further provided that before a production license was issued the Minister must be "satisfied that the production proposed by the applicant for a license to produce is consistent with sound utilization and

' O.C. 1733/69. Sask. Reg. 287/69, Saskatchewan Gazette, November 21, 1969, at 568-69.

2 R.S.S. 1965, c. 50.

${ }^{3}$ Reg. 2 and 3 of O.C. 1733/69, supra, $n .1$ provided as follows:

2.-(1) On and after January 1, 1970, the production of potash is prohibited unless a producing license authorizing the production is granted by the minister which license shall be in such form and subject to such conditions as the minister may determine.

(2) The minister may issue a producing licence to produce potash in compliance with these regu. lations in such form as the minister may determine and subject to such conditions as may be stated in the licence, or he may refuse to grant a producing licence.

3.-(1) On and after January 1, 1970, the disposal of potash is prohibited unless a licence authorizing the disposal is granted by the minister.

(2) The minister may issue a licence to dispose of potash in compliance with these regulations and subject to such conditions as may be stated in the licence, or he may refuse to grant a disposal licence.

- O.C. 404/70, Sask. Reg. 64/70, Saskatchewan Gazette, March 26, 1970, at 127. 
conservation priciples relating to the potash resources of the province..."5

To determine "the proper utilization and conservation of potash and the protection of correlative rights of the owners of mineral rights," the Minister may order a public inquiry to determine any or all of the following: 6

(a) the economic viability of the proposed production, including such things as cost of production, method of production, reserves for control of pollution, methods of mining, costs of transportation and sale price; 7

(b) the productive capacity of each potash mining property;

(c) a proportionate share of production, if any, that may be allocated to each potash mining property required to meet the market demand for potash;

(d) the demand for potash or potash products for reasonable current requirements and current consumption or use within and outside the province, together with such amounts as are reasonably necessary for building up or maintaining reasonable storage reserves and working stocks of potash and potash products;

(e) any other matter that the Minister deems advisable.

Notice of the inquiry is to be published in the Saskatchewan Gazette at least ten days prior to the date set for the inquiry, ${ }^{8}$ and a similar notice is to be given by registered mail to "every owner of a mine that produces potash or is, within six months from the date set for the inquiry, likely to produce potash."9 This inquiry is conducted by The Potash Conservation Board consisting of three persons, of which the Deputy Minister of Mineral Resources is the chairman.

At the present time, producing licenses are issued for a three month period and prior to the end of each three month period, there is a further inquiry to determine the proper utilization and conservation of potash.

So far as the procedure at the hearing is concerned, it can be generally stated as follows:

1. The solicitor for the Department of Mineral Resources opens the inquiry and establishes the authority and purpose of same.

2. Each company wishing to be heard so indicates and gives the names of the persons who will be giving evidence for the company.

3. Each company is then asked in turn to file and present its submission as to:

(i) capacity of its mining property to produce;

\footnotetext{
${ }^{3}$ U.C. $404 / 70$ provided as follows:

The Potash Conservation Regulations, 1969, are amended as hereinafter set forth. 1. Section 2 is rescinded and the following substituted therefor:

“2.-(1) The production of potash is prohibited unless a producing licence authorizing the production is granted by the minister which licence may be issued on such basis and in such form and subject to such conditions as the minister may deem appropriate to each proposed production.

(2) Where the minister is satisfied that the production proposed by the applicant for a licence to produce is consistent with sound utilization and conservation principles relating to the potash resources of the province he may issue a producing licence, and where not so satisfied he may refuse to issue such licence."

2. Section 3 is rescinded.

3. Clause (a) of section 4 is rescinded and the following is substituted therefor:

"(a) the economic viability of the proposed production, including such things as cost of production, method of production, reserves for control of pollution, methods of mining, costs of transportation and sale price".

6 Reg. 4, as amended.

7 This provision replaces the original provision which read as follows:

(a) a fair and reasonable price to the producer of potash, free on board at the potash plant gate in Saskatchewan, for all potash produced in the province.

- Reg. 4 (2).
} 
(ii) definite and bona fide requirements for potash for the particular quarter of the year under consideration;

(iii) forecast of potash requirements for the next two succeeding quarters and an estimate for the quarter after the said next two succeeding quarters;

(iv) any other comments that may be relevant to the issues before the Board.

4. Those giving evidence are subject to cross-examination by other interested parties and by the Board.

5. Witnesses are sworn. (Under the Regulations every member of the Board has all the powers of a commissioner under The Public Inquiries Act. ${ }^{10}$ )

6. Each interested party is given an opportunity to sum up its position.

7. The proceedings are recorded and transcribed and copies may be obtained from the public stenographer.

So far as the form of the submission and the evidence presented to the Board is concerned, every person who intends to be heard must file with the Board, not later than a certain number of days prior to the hearing, on forms supplied by the Department of Mineral Resources, a statement for submission covering generally, the following:

(a) The rated capacity of the potash mining property on July 1st, 1968 , or if not in operation or in full operation on that date, the completion schedule of capacity of the property as proposed to be effective on and prior to January 1st, 1970, expressed in short tons of potassium oxide equivalent, which schedule was announced on or prior to July 1st, 1968;

(b) The Company's definite and bona fide requirements for disposal of potash for the next quarter;

(c) The forecast of the company of its requirements for disposal of potash for the next three succeeding quarters;

(d) A reasonable estimate of the total market demand for potash available to Saskatchewan producers for said quarters;

(e) A statement of verification of inventory as of a certain date;

(f) A statement of estimated inventory as of a certain date.

The Board reports to the Minister and if he decides that it is advisable to limit the total amount of potash that may be produced in the Province, he allocates the allowable production among the potash mining properties in production in the Province. ${ }^{11}$ The potash production allocation formula is as follows: The quarterly allowable production for a producer equals $\mathrm{A}+\mathrm{B}+\mathrm{C}$ where:

\footnotetext{
- Reg. 4(3).

10 Reg. 4(7).

"Reg. 5(1) provides as follows:

Where the minister decides that it is advisable to limit the total amount of potash that may be produced in the province he shall allocate the allowable production among the potash mining properties in production in the province and may, in determining such allocation, consider the following factors: (a) basic allowables;

(b) definite and bona fide requirements for disposal:

(c) inventory requirements;

(d) any other matter that the minister deems advisable.
} 
$\mathrm{A}=$ basic allowable $=0.4^{12}$ times the quarterly capacity of the producer;

$\mathrm{B}=$ nomination allowable = " $\mathrm{X}$ " $\mathrm{x}$ " $\mathrm{Y}$ "/" $\mathrm{Z}$ " where:

"X" = total quarterly nominations from all producers less their total basic allowables;

"Y"13 = nomination(s) from the producer less his basic allowable;

" $\mathrm{Z}$ " = the amount by which the total nominations of all producers who nominate in excess of their respective basic allowables exceeds the total basic allowables of such producers;

$\mathrm{C}=$ inventory allowable $=$ production to maintain inventory at $\mathbf{a}$ level equal to....... per cent of the producer's storage capacity or ...... tons, whichever is the lesser.

(This may be clear to a professional engineer, or a group of them, but lawyers may find the same somewhat incomprehensible.)

At any time the Minister may amend, revise or vary the allowable production allocated to any or all potash mining properties in production, with or without an inquiry, as he deems advisable, to meet changing conditions or circumstances. ${ }^{14}$

Each producing company must make a monthly report to the Department of Mineral Resources as to the production of potash and the disposition of potash. ${ }^{15}$

\section{OBSERVATIONS}

There was no great public outcry by the potash companies as to this prorationing, and accordingly, one could conclude that the companies are generally in agreement with the prorationing of production. In fact, newspaper accounts, if they are correct, confirm this view. There is some belief that the Regulations are of an emergency nature and when the emergency passes away, so will the Regulations. Time will tell.

There is no specific mention anywhere in the regulations of a minimum price for potash. Nevertheless, the intention of the Regulations is to regulate the price of potash by limiting its production. At the present time the minimum price for potash has been set by the Province at $\$ 18.75$ a ton, or more accurately at $.333 / 4 \notin$ Canadian per unit of potassium oxide. Producing licenses, as issued, set forth the minimum price at which potash in terms of potassium oxide equivalent, can be sold.

It can be surmised that, initially, companies with contracts for a fixed period, terminating subsequent to January 1st, 1970, for sale of potash at a price less than $\$ 18.75$ a ton, had a problem. This was alleviated in part by the understanding with the Minister that provided a sale in fact had been made, the potash could be delivered subsequent to January 1st, 1970 , at a price less than $\$ 18.75$ a ton, provided that

12 If the total of the quarterly nominations from all producers is less than four-tenths of the total of the quarterly capacities of all producers, use a fraction equal to the total of quarterly nominations from all producers, divided by the total of quarterly capacities of all producers.

13 If the basic allowable is equal to or is more than the nominations from the producer, use 0 and in this case $B=0$.

1" Reg. 5(2).

is Reg. 6. 
such delivery was from inventory on hand prior to January 1st, 1970, and not from production thereafter. Unfortunately, for those companies unable to so fulfill their contractual commitments, the author is unaware of what they did or could do. It does appear that it might be a case of "frustration" but the solution may not be that simple.

Earlier, it was indicated that the potash companies were unable or unwilling to voluntarily agree among themselves to limit production. It is suggested that, so far as being unable to so agree, the American companies were considerably restricted in what they might do or would like to do in this regard by reason of the anti-trust laws of the United States. Apparently, anti-trust laws do not present a problem if in fact the production is being limited as a result of governmental action, as is the case with this prorationing.

While anti-dumping duties have been levied by the United States on Saskatchewan potash, it appears that Saskatchewan producers can live with them. Presumably the fact of agreement between Saskatchewan and New Mexico as to production softened this potential blow, which agreement, it is understood, provided that New Mexico would not increase its production to take up the slack in supply resulting from the limitation of production by Saskatchewan.

Perhaps the most interesting aspect of this matter, from an academic standpoint, is whether or not the regulations are ultra vires of the powers of the Province of Saskatchewan. The author is not a constitutional law expert, and in any event time does not permit a careful consideration of this point, but it would appear that there is a distinct possibility that the regulations are ultra vires as being an interference with trade and commerce, the regulation of which is exclusively within the power of the Parliament of Canada.

\section{CONCLUSION}

To date, prorationing of potash production appears to be working reasonably well. Whether the regulations are intra vires or ultra vires will have to wait until someone decides to test them, but from a practical standpoint, anyone so disposed must do so in the knowledge that when you fight the Government, it is possible to "win the battle but lose the war." 